SHATTERING BIOPOLITICS 
FORDHAM UNIVERSITY PRESS NEW YORK 2021

COMMONALITIES

Timothy C. Campbell, series editor 


\section{SHATTERING BIOPOLITICS}

Militant Listening and the Sound of Life 


\section{Copyright (c) 2021 Fordham University Press}

All rights reserved. No part of this publication may be reproduced, stored in a retrieval system, or transmitted in any form or by any means-electronic, mechanical, photocopy, recording, or any otherexcept for brief quotations in printed reviews, without the prior permission of the publisher.

Fordham University Press has no responsibility for the persistence or accuracy of URLs for external or third-party Internet websites referred to in this publication and does not guarantee that any content on such websites is, or will remain, accurate or appropriate.

Fordham University Press also publishes its books in a variety of electronic formats. Some content that appears in print may not be available in electronic books.

Visit us online at www.fordhampress.com.

Library of Congress Cataloging-in-Publication Data

Names: Waltham-Smith, Naomi, 1983- author.

Title: Shattering biopolitics : militant listening and the sound of life / Naomi Waltham-Smith.

Description: First edition. | New York : Fordham University Press, 2021. | Series: Commonalities | Includes bibliographical references and index.

Identifiers: LCCN 2020058362 | ISBN 9780823294862 (hardback) | ISBN 9780823294879 (paperback) | ISBN 9780823294886 (epub)

Subjects: LCSH: Biopolitics-Philosophy. | Sound (Philosophy)

Classification: LCC JA80.W34 2021 | DDC 320.01-dc23

LC record available at https://lccn.loc.gov/2020058362

Printed in the United States of America

$232221 \quad 54321$

First edition 
for my mother, who never wanted to hang up

The invention of writing is an urgent defense against pillaging, massacre, forgetting...

You are dead. I snatch the world from you. I take your breath away. It's over. Done for [ fichu]. Finished. Says mortality.-No! I cry.

—HÉLÈnE CIXOUS, AYAÏ 
